\title{
Soybean meal as a source of protein in formulated diets for tiger grouper, Epinephelus fuscoguttatus juvenile. Part II: Improving diet performances with phytase supplementation
}

\author{
Rossita Shapawi ${ }^{{ }^{*}}$, Isabella Ebi ${ }^{1}$, Annita Yong $^{1}$, Moris Chong ${ }^{2}$, Lu Kien Chee ${ }^{2}$, Ahemad Sade $^{2}$ \\ ${ }^{1}$ Borneo Marine Research Institute, Universiti Malaysia Sabah, Jalan UMS, 88450 Kota Kinabalu, Sabah, Malaysia; \\ ${ }^{*}$ Corresponding Author: rossita@ums.edu.my \\ ${ }^{2}$ Department of Fisheries, Sabah, 4th Floor, Wisma Pertanian Sabah, Jalan Tasik, 88624 Kota Kinabalu, Sabah, Malaysia \\ Received 22 April 2013; revised 23 May 2013; accepted 9 June 2013 \\ Copyright (C) 2013 Rossita Shapawi et al. This is an open access article distributed under the Creative Commons Attribution License, \\ which permits unrestricted use, distribution, and reproduction in any medium, provided the original work is properly cited.
}

\section{ABSTRACT}

The present study was conducted as a continuation of our previous study on the effects of fish meal replacement with soy bean meal, SBM in the diets of tiger grouper, Epinephelus fuscoguttatus which revealed the possible level of fish meal protein replacement of $30 \%$ with positive effect of phytase supplementation in one of the test diet. In the present study, all experimental diets with SBM inclusion $(10 \%, 20 \%, 30 \%$, $40 \%$ replacement levels) were supplemented with phytase and fed to juvenile tiger grouper with initial body weight of $44.57 \pm 0.28 \mathrm{~g}$ for eight weeks. Apart from the effects on growth performance, diet utilization and fish whole-body composition, apparent digestibility coefficient of diets was also measured. Similar findings to our previous experiment were observed in the present study. Diet SM40P (40\% replacement level) had produced the poorest growth performance and feed conversion ratio (FCR). However, it was observed that FCR of SM40P was improved when compared to SM40 (without phytase) in our previous experiment. Other than that, SBMbased diets were performed as good as the control diet in terms of growth, feed utilization and survival rate. Replacement of fish meal did not significantly influence body composition, except for whole body lipid content in SM40P. In general, dry matter and protein apparent digestibility coefficients (ADC) of the test diets were influenced by SBM inclusion in the diets. However, crude lipid ADC was very high in all dietary treatments indicating efficient utilization of dietary lipid by juvenile tiger grouper. The findings of the present study confirmed that SBM can be used to replace FM at a level of up to $30 \%$ and supplementation of phytase in SBMbased diets is recommended to improve the diet performance.

Keywords: Epinephelus fuscoguttatus; Soy Bean Meal; Phytase Supplementation; Digestibility Coefficient

\section{INTRODUCTION}

In general, phytase activity in fish is low [1] making this a limitation in using plant-based protein in the diet. Fortunately, commercial phytase is now available in the market for inclusion in animal diets. In fish, positive results have been reported when phytase was included in the formulated diets of at least the rainbow trout Onchorhynchus mykiss, Atlantic salmon Salmo salar, red sea bream Sparus aurata and humpback grouper Cromileptis altivelis [2-5]. To determine the full potential of soy bean meal (SBM) as a source of protein in fish diets, investigation on the effect of phytase supplementation in SBMbased diets should be further explored in other fish species.

In our previous study, the results showed that SBM can be used to replace FM protein at a level of up to $30 \%$ in diet formulated for tiger grouper juveniles. In addition, fish fed with phytase-supplemented diet (SM20P) possessed better feed utilization than those without phytase supplementation. Therefore, the present study was conducted to evaluate the full potential of SBM-based diets 
supplemented with phytase in terms of growth performance, feed utilization, body composition and digestibility of tiger grouper.

\section{MATERIALS AND METHODS}

\subsection{Experimental Diets}

In this trial, 5 isonitrogenous (50\% protein), isolipidic (16\% lipid) and isoenergertic $(365.8 \mathrm{kcal} / 100 \mathrm{~g})$ experimental diets were formulated with SBM replacing FM protein at 0 (SM0), 10 (SM10), 20 (SM20), 30 (SM30) and $40 \%$ (SM40) with phytase (Natuphos ${ }^{\circledR} 10000 \mathrm{G}$ ) supplementation of $2000 \mathrm{FTU} / \mathrm{kg}$ except for the control diet. Fish feeds were prepared by mixing all dry ingredients followed by fish oil. Phytase was dissolved in distilled water and added to the mixture to form a dough. Pellets of $3 \mathrm{~mm}$ diameter were produced after drying in an oven at $40^{\circ} \mathrm{C}$ for 6 hours. Dietary ingredients and formulation are shown in Table 1.

\subsection{Experimental Fish and Culture Condition}

The feeding trial was conducted at the hatchery of

Table 1. Ingredients (g/100g dry weight) and proximate composition ( $\%$ dry matter) of experimental diets.

\begin{tabular}{|c|c|c|c|c|c|}
\hline \multirow{2}{*}{ Ingredients } & \multicolumn{5}{|c|}{ Diets } \\
\hline & SM 0 & SM 10P & SM 20P & SM 30P & SM 40P \\
\hline Fish meal & 67.6 & 60.8 & 54.1 & 47.3 & 40.5 \\
\hline Soybean meal & 0.0 & 10.4 & 20.8 & 31.2 & 41.6 \\
\hline Tapioca starch & 0.4 & 0.4 & 0.4 & 0.4 & 0.4 \\
\hline$\alpha$-Cellulose & 16.7 & 12.5 & 8.4 & 4.2 & 0.0 \\
\hline $\mathrm{CMC}$ & 1.5 & 1.5 & 1.5 & 1.5 & 1.5 \\
\hline Vitamin premix & 2.0 & 2.0 & 2.0 & 2.0 & 2.0 \\
\hline Mineral premix & 1.0 & 1.0 & 1.0 & 1.0 & 1.0 \\
\hline Dicalcium phosphate & 1.0 & 1.0 & 1.0 & 1.0 & 1.0 \\
\hline Chromium oxide & 0.5 & 0.5 & 0.5 & 0.5 & 0.5 \\
\hline Fish oil & 8.9 & 9.4 & 9.9 & 10.4 & 11 \\
\hline Phytase & 0.00 & 0.02 & 0.02 & 0.02 & 0.02 \\
\hline \multicolumn{6}{|l|}{ Proximate composition } \\
\hline Moisture & 10.2 & 10.5 & 11.1 & 10.1 & 10.2 \\
\hline Crude protein & 50.3 & 50.2 & 50.6 & 50.6 & 50.5 \\
\hline Crude lipid & 16.8 & 16.3 & 16.1 & 15.8 & 16.3 \\
\hline Crude fiber & 0.1 & 0.41 & 0.65 & 1.0 & 1.31 \\
\hline Ash & 10.3 & 10.2 & 10.6 & 11.8 & 12.4 \\
\hline
\end{tabular}

Fisheries Department of Sabah, Tanjung Badak, Tuaran, Sabah using tiger grouper juvenile produced in this facility. Prior to the feeding trial, fish were acclimatized to experiment condition and fed to control diet (SM0) for 2 weeks. After aclimization period, 225 tails of fish with an average initial body weight of $44.57 \pm 0.28$ were randomly distributed into 15 cylindrical cages with $50 \mathrm{~cm}$ depth and $50 \mathrm{~cm}$ diameter and placed in 3 tanks of 5 tonnes fiberglass tank. Tanks were supplied with aeration and flow-through water system $\left(30 \mathrm{~L} \cdot \mathrm{min}^{-1}\right)$ was implemented. Fish were hand-fed with experimental diets twice a day at satiation level for 8 weeks.

\subsection{Fish Sampling and Fecal Collection}

At the beginning and end of the feeding trial, 5 fish from an initial pool of fish and each dietary treatment were sampled for whole-body proximate composition. At the end of feeding trial, fish from each of dietary treatment was pooled for fecal collection. About 20 minutes after feeding, all tanks were cleaned by siphoning out the uneaten feed. After two hours of feeding, the fresh and intact feces of tiger grouper juvenile were collected at the bottom of net cages by slowly siphoning the tank bottom [6]. The collected feces were then rinsed with distilled water, placed on a filter paper to absorb the moisture of the feces, and immediately frozen [7].

\subsection{Proximate Composition}

Proximate analysis of fish feeds, whole body samples, and feces were determined following AOAC [8] method. Crude protein was determined using the Kjeldahl method using an automatic system (Kjeltec 2300). Crude lipid was determined gravimetrically using ether-extraction method in a soxhlet extraction unit (Soxtec 2043). Ash content was determined as the residue remaining after incineration of samples at $550^{\circ} \mathrm{C}$ in a muffle furnace for 6 hours.

\subsection{Apparent Digestibility Coefficient Analysis}

Prior to analysis, collected feces was dried in a freeze dryer (LTE Scientific Freeze Dryer, LTE Scientific LTD, Great Britain) and ground using a mortar and pestle. Apparent digestibility coefficient analysis was done by acid digestion method of test diets and feces. Chromium oxide $\left(\mathrm{Cr}_{2} \mathrm{O}_{3}\right)$ was determined by a spectrophotometer method described by Furukawa and Tsukahara [9]. Apparent digestibility coefficient, ADC of experimental diets was determined using the following formula:

ADCs of nutrient $(\%)=100 \times[1-(\%$ feces nutrient/ $\%$ dietary nutrient $) \times(\%$ dietary chromic oxide/feces chromic oxide)] 


\subsection{Calculation}

Growth performance, feed utilization efficiency and body indices were calculated as follows:

$\%$ weight gain $=$ percentage of initial body weight at the end of trial;

Specific growth rate $(\mathrm{SGR})=[(\ln$ final weight $-\ln$ initial weight)/days] $\times 100$;

Feed conversion ratio $(\mathrm{FCR})=$ dry feed consumed $(\mathrm{kg}) /$ wet weight gain $(\mathrm{kg})$; 100 ;

Condition factor $(\mathrm{CF})=\left[\right.$ fish weight $\left./(\text { total length })^{3}\right] \times$

Hepatosomatic index $(\mathrm{HSI})=$ (liver weight $/$ fish weight) $\times 100$;

Viserosomatic index $(\mathrm{VI})=$ (viseral weight/body weight) $\times 100$.

\subsection{Statistical Analysis}

The fish growth performances, feed utilization, and proximate composition of diets and whole body fish, and ADCs of diets were analyzed by one-way analysis of variance (ANOVA) for significant differences. The homogeneity of variances was tested using Levene's test, and multiple comparisons among treatments were performed using a Duncan's multiple range test. Significant level was set at $P<0.05$. The statistical package IBM SPSS Statistics 19 for Windows was used for all statistical analyses.

\section{RESULTS}

\subsection{Growth Performance, Survival and Diet Utilization of Tiger Grouper}

Table 2 shows the growth performances of tiger grouper in the 8 weeks feeding trial. The fish fed SM30P gained the highest BWG $(82.5 \mathrm{~g})$ followed by fish fed SM20P (81.4\%), SM0 (80.3\%), SM40P (72.90\%), and SM10P (79.4\%). The fish fed SM40P showed significantly lower $(P<0.05)$ BWG than those fed other diets. The SGR of fish in SM40P group was significantly lower than in SM30P but not to other diets. Juvenile tiger grouper in all treatments yielded high survival rates ranging from $97.8 \%$ to $100.0 \%$ and these values were not significantly different $(P<0.05)$ among treatments.

The diet utilization of tiger grouper in the 8 weeks feeding trial is shown in Table 3 . There was no significant difference $(P<0.05)$ observed in feed intake, FI of fish fed different level of SBM in the diets. FCR of the control diet (1.25) was not significantly different $(P>$ $0.05)$ from FCR of SM10P (1.32), SM20P and SM30P (1.33). However, FCR of SM40P (1.47) was significantly poorer $(P<0.05)$ than the FCR of the control diet (SM0). The protein efficiency ratio (PER) and net protein utilization (NPU) ranged from 1.37 to 1.60 and 23.94 to 31.41 , respectively, and were not affected by the dietary treatments.

Except for fish fed SM40P, replacement of FM with SBM supplemented with phytase did not significantly influence the whole body proximate of juvenile tiger grouper. The fish whole body moisture ranged from $69.4 \%$ to $70.0 \%$. The highest whole body protein was observed in fish fed SM30P (19.0\%) followed by fish fed SM10 (18.6\%), SM20P (18.5\%), and SM0 (18.2\%) and SM40P $(18.2 \%)$. The body lipid content of fish fed SM40 $(5.6 \%)$ was significantly lower $(P<0.05)$ than the other treatments $(6.4 \%$ to $6.8 \%)$. The whole-body ash of fish fed SBM-based diets supplemented with phytase and the control diet was not significantly different $(5.9 \%$ to $6.2 \%$ ) (Table 4).

\subsection{Body Condition Indices of Tiger Grouper Juveniles}

The highest VSI was found in fish fed SM10P (9.64), followed by SM30P (9.63), SM40P (8.86), SM20P (8.83) and SM0 (8.79). There were no significant differences $(P$ $<0.05)$ of HSI observed among dietary treatments. Similarly, replacement of FM with SBM supplemented with phytase did not significantly affect the CF of the fish which ranged from 1.76 to 1.81 (Table 5).

\subsection{Apparent Digestibility Coefficients (ADCs) of the Experimental Diets}

Apparent digestibility coefficients (ADCs) of diets are presented in Table 6. There was no definite trend in the

Table 2. Growth performances of tiger grouper fed graded levels of SBM supplemented with phytase (Mean \pm SD).

\begin{tabular}{|c|c|c|c|c|}
\hline Diets & FBW (g) & BWG \% & SGR \% & Survival \\
\hline SM0 & $81.0 \pm 1.83^{\mathrm{ab}}$ & $80.3 \pm 1.68^{\mathrm{a}}$ & $1.03 \pm 0.01^{\mathrm{ab}}$ & $97.8 \pm 3.85^{\mathrm{a}}$ \\
\hline SM10P & $81.2 \pm 2.39^{\mathrm{ab}}$ & $79.4 \pm 3.73^{\mathrm{a}}$ & $1.03 \pm 0.06^{\mathrm{ab}}$ & $100.0 \pm 0.00^{\mathrm{a}}$ \\
\hline SM20P & $81.1 \pm 4.42^{\mathrm{ab}}$ & $81.4 \pm 5.17^{\mathrm{a}}$ & $1.04 \pm 0.04^{\mathrm{ab}}$ & $97.8 \pm 3.85^{\mathrm{a}}$ \\
\hline SM30P & $82.2 \pm 0.65^{\mathrm{a}}$ & $82.5 \pm 1.39^{\mathrm{a}}$ & $1.06 \pm 0.03^{\mathrm{a}}$ & $100.0 \pm 0.00^{\mathrm{a}}$ \\
\hline SM40P & $75.5 \pm 4.06^{\mathrm{b}}$ & $72.9 \pm 3.81^{b}$ & $0.96 \pm 0.06^{\mathrm{b}}$ & $97.8 \pm 3.85^{\mathrm{a}}$ \\
\hline
\end{tabular}

Initial fish body weight $=44.57 \pm 0.28 \mathrm{~g}$; Different superscripted letters in each column indicate significant differences $(P<0.05)$. 
Table 3. Feed utilization of tiger grouper fed graded levels of SBM supplemented with phytase (Mean \pm SD).

\begin{tabular}{ccccc}
\hline Diets & Total FI (g/fish) & FCR & PER & NPU \\
\hline SM0 & $45.1 \pm 1.50^{\mathrm{a}}$ & $1.25 \pm 0.06^{\mathrm{a}}$ & $1.60 \pm 0.08^{\mathrm{a}}$ & $26.81 \pm 3.29^{\mathrm{a}}$ \\
SM10P & $47.4 \pm 0.60^{\mathrm{a}}$ & $1.32 \pm 0.08^{\mathrm{ab}}$ & $1.51 \pm 0.09^{\mathrm{a}}$ & $26.63 \pm 4.53^{\mathrm{a}}$ \\
SM20P & $48.2 \pm 2.52^{\mathrm{a}}$ & $1.33 \pm 0.17^{\mathrm{ab}}$ & $1.50 \pm 0.19^{\mathrm{a}}$ & $28.86 \pm 0.79^{\mathrm{a}}$ \\
SM30P & $49.3 \pm 0.35^{\mathrm{a}}$ & $1.33 \pm 0.02^{\mathrm{ab}}$ & $1.47 \pm 0.06^{\mathrm{a}}$ & $31.41 \pm 3.81^{\mathrm{a}}$ \\
SM40P & $48.1 \pm 1.32^{\mathrm{a}}$ & $1.47 \pm 0.15^{\mathrm{b}}$ & $1.37 \pm 0.17^{\mathrm{a}}$ & $23.94 \pm 4.55^{\mathrm{a}}$ \\
\hline
\end{tabular}

Different superscripted letters in each column indicate significant differences $(P<0.05)$.

Table 4. Whole body proximate composition (\% wet weight) of tiger grouper fed graded levels of SBM supplemented with phytase for 8 weeks (Mean $\pm \mathrm{SD})$.

\begin{tabular}{ccccc}
\hline Diets & Moisture & CP & CL & Ash \\
\hline SM0 & $69.4 \pm 0.47^{\mathrm{a}}$ & $18.2 \pm 0.69^{\mathrm{a}}$ & $6.8 \pm 0.15^{\mathrm{a}}$ & $6.1 \pm 0.73^{\mathrm{a}}$ \\
SM10P & $69.8 \pm 0.13^{\mathrm{a}}$ & $18.6 \pm 0.95^{\mathrm{a}}$ & $6.8 \pm 0.30^{\mathrm{a}}$ & $5.9 \pm 0.30^{\mathrm{a}}$ \\
SM20P & $69.6 \pm 0.49^{\mathrm{a}}$ & $18.5 \pm 0.49^{\mathrm{a}}$ & $6.4 \pm 0.47^{\mathrm{a}}$ & $5.8 \pm 0.18^{\mathrm{a}}$ \\
SM30P & $69.5 \pm 0.47^{\mathrm{a}}$ & $19.0 \pm 0.96^{\mathrm{a}}$ & $6.5 \pm 0.36^{\mathrm{a}}$ & $6.2 \pm 0.45^{\mathrm{a}}$ \\
SM40P & $70.0 \pm 0.49^{\mathrm{a}}$ & $18.2 \pm 1.17^{\mathrm{a}}$ & $5.6 \pm 0.27^{\mathrm{b}}$ & $6.0 \pm 0.09^{\mathrm{a}}$ \\
\hline
\end{tabular}

Initial whole-body proximate composition was moisture $69.8 \%$, crude protein $18.1 \%$, crude lipid $6.5 \%$ and ash $5.8 \%$. Different superscripted letters in each column indicate significant differences $(P<0.05)$.

Table 5. Body indices of tiger grouper fed graded levels of SBM supplemented with phytase (Mean \pm SD).

\begin{tabular}{cccc}
\hline Diets & VSI & HSI & CF \\
\hline SM0 & $8.79 \pm 0.28^{\mathrm{a}}$ & $0.91 \pm 0.04^{\mathrm{a}}$ & $1.78 \pm 0.02^{\mathrm{a}}$ \\
SM10P & $9.64 \pm 0.07^{\mathrm{b}}$ & $1.17 \pm 0.02^{\mathrm{a}}$ & $1.81 \pm 0.05^{\mathrm{a}}$ \\
SM20P & $8.83 \pm 0.76^{\mathrm{ab}}$ & $1.15 \pm 0.13^{\mathrm{a}}$ & $1.78 \pm 0.05^{\mathrm{a}}$ \\
SM30P & $9.63 \pm 033^{\mathrm{b}}$ & $1.19 \pm 0.06^{\mathrm{a}}$ & $1.76 \pm 0.03^{\mathrm{a}}$ \\
SM40P & $8.86 \pm 0.35^{\mathrm{ab}}$ & $1.10 \pm 0.04^{\mathrm{a}}$ & $1.76 \pm 0.03^{\mathrm{a}}$ \\
\hline
\end{tabular}

Different superscripted letters in each column indicate significant differences $(P<0.05)$.

Table 6. Apparent digestibility coefficient (ADCs) of experimental diets (Mean $\pm \mathrm{SD}$ ).

\begin{tabular}{|c|c|c|c|}
\hline & Dry matter $(\%)$ & Crude protein (\%) & Crude lipid (\%) \\
\hline SM0 & $65.6 \pm 1.10^{\mathrm{b}}$ & $94.2 \pm 0.47^{\mathrm{a}}$ & $97.7 \pm 0.57^{\mathrm{a}}$ \\
\hline SM10P & $64.3 \pm 2.00^{\mathrm{b}}$ & $94.0 \pm 0.49^{\mathrm{a}}$ & $97.2 \pm 0.24^{\mathrm{a}}$ \\
\hline SM20P & $58.5 \pm 1.00^{\mathrm{a}}$ & $93.4 \pm 0.31^{\mathrm{a}}$ & $97.2 \pm 0.15^{\mathrm{a}}$ \\
\hline SM30P & $72.7 \pm 2.00^{\mathrm{c}}$ & $93.6 \pm 0.84^{\mathrm{a}}$ & $97.2 \pm 0.15^{\mathrm{a}}$ \\
\hline SM40P & $74.2 \pm 0.95^{\mathrm{c}}$ & $90.6 \pm 0.49^{b}$ & $97.1 \pm 0.32^{\mathrm{a}}$ \\
\hline
\end{tabular}

Different superscripted letters in each column indicate significant differences $(P<0.05)$.

dry matter ADCs ( $64.3 \%$ to $74.2 \%$ ) of diets as a result of SBM inclusion. Diet SM40P showed the lowest crude protein ADCs and this value was significantly lower than the values in other treatments. Lipid ADCs of all experimental diets were very high in the present study ranging from $97.1 \%$ to $97.7 \%$, with no significant dif- ference detected in all diets.

\section{DISCUSSION}

In the present study, diet with SBM replacing 30\% of FM protein and supplemented with phytase (SM30P) 
was the best to support growth, feed utilization and digestibility of tiger grouper juvenile. Fish fed with SM30P showed higher FBW, BWG, and SGR values than in other treatments including FM-based diet (SM0). A similar result was observed in red sea bream, Pagrus major where the growth performance of the juvenile fish (24 $\mathrm{g}$ average initial body weight) was not affected after being fed with $30 \%$ of SBM inclusion in diets supplemented with 2000 FTU phytase after 6 weeks of feeding trial [4]. The results also indicated that the phytase supplementation at 2000 FTU was sufficient to break down the phytate content in the $30 \%$ replacement level with SBM in diet of juvenile tiger grouper. In fact, phytase supplementation in all SBM-based diets was found to generally improve the feed utilization of fish. Rachmansyah et al. [5] reported that humback grouper was able to utilize SBM at 24\% FM replacement level when supplemented with Rhonozome-P at $0.075 \%$. Dissimilarities between authors may due to the phytase type and dose used in the experiment.

FI was not affected by the inclusion of SBM in the diets. Diets with plant-based protein are often reported to decrease FI intake in fish due to the poor diet palatability $[10,11]$. However, in studies conducted by Boonyaratpalin et al. [12] and Tomás et al. [13], the FI of Asian seabass (Lates calcarifer) and Mediterranean yellowtail (Seriola dumerili) were not affected when fed with $28.5 \%$ and $30 \%$ SBM, respectively. There was even a case of increased FI of fish when fed with SBM-based diet. Ogunkoya et al. [14] reported that FI of rainbow trout (Onchorhychus mykiss) increased when SBM inclusion was increased up to $20 \%$.

Except in SM40P, no significant differences were observed in the FCR, PER, and NPU between the SBMbased diets and the control diet (SM0). Slightly reduced feed utilization efficiency in SM40P could be due to the higher content of insoluble carbohydrates such as cellulose as a result of higher inclusion of SBM [15-19]. However, it is interesting to note that, FCR of SM40P was improved (1.47) compared to SM40 diet (1.77) in our previous study (without phytase). In fact, the FCR of all diets in the present study were below 1.5 which is considered a good FCR value for aquaculture feed. Apart from the phytase supplementation, larger size of fish was reported to better utilize the plant protein [20]. The size of fish used in the present study (44 g) was slightly bigger than the size of fish in our previous study (13 g). Therefore, it is recommended to include SBM in the diet of larger fish due to the better tolerance of fish at this size to plant-protein ingredients compared to when they are smaller. High survival rates (mortality $0.28 \%$ ) of tiger grouper were observed in the present study indicating fish health were generally unaffected when fed diets based on SBM with phytase supplementation. It is also interesting to note that the performance of SM10P was better than SM10 in the previous experiment indicating the positive role of phytase in improving nutrient utilization by the fish.

Generally, the levels of SBM in the diets supplemented with phytase did not affect the body composition and body indices of tiger grouper juvenile. There was no significant difference found in the body composition (moisture, crude protein, and ash) in all dietary treatments except the crude lipid. Fish that fed SM40P had significantly lower crude lipid content than those that fed other treatments. Lower body lipid composition may be related to the lower growth and poor diet utilization of fish fed SM40P.

The apparent digestibility coefficients (ADCs) of both protein and lipid in all treatments were considered high, ranging from $90.6 \%$ to $94.2 \%$ and $97.1 \%$ to $97.7 \%$, respectively. High ADCs of protein indicated the good digestibility of SBM-based diets [21]. Grouper species has been reported to be able to utilize dietary lipid of different sources efficiently $[6,22,23]$. The findings of the present study were also comparable to similar studies on other marine species such as Japanese flounder [24], Atlantic salmon [25], European seabass [26], and gilthead seabream [27].

Therefore, it can be concluded that SBM can be used as a good source of protein in the formulated diets of tiger grouper juveniles. Replacement of fish meal protein with SBM at 30\% replacement level together with phytase supplementation is recommended in the formulation of SBM-based diets for the tiger grouper juvenile.

\section{REFERENCES}

[1] Kumar, V., Sinha, A.K., Makkar, H.P.S., Boeck, G.De. and Becker, K. (2011) Phytate and phytase in fish nutrition. Journal of Animal Physiology and Animal Nutrition, 96, 335-364. doi:10.1111/j.1439-0396.2011.01169.x

[2] Wang, F., Yang, Y.H., Han, Z.Z., Dong, H.W., Yang, C.H. and Zou, Z.Y. (2009) Effects of phytase pretreatment of soybean meal and phytase-sprayed in diets on growth, apparent digestibility coefficient and nutrient excretion of rainbow trout (Oncorhynchus mykiss Walbaum). Aquaculture International, 17, 143-157. doi:10.1007/s10499-008-9187-5

[3] Carter, C.G. and Sajjadi, M. (2011) Low fishmeal diets for Atlantic salmon, Salmo salar L., using soy protein concentrate treated with graded levels of phytase. Aquaculture International, 19, 431-444. doi:10.1007/s10499-010-9358-z

[4] Biswas, A.K., Kaku, H., Ji, S.C., Seoka, M. and Takii, K. (2007) Use of soybean meal and phytase for partial replacement of fishmeal in the diet of red sea bream, $\mathrm{Pa}$ grus major. Aquaculture, 267, 284-291. doi:10.1016/j.aquaculture.2007.01.014

[5] Rachmansyah, Usman, Makmur and Ahmad, T. (2005) 
Substitution of fishmeal with soybean meal in humpback grouper, Chromileptes altivelis juvenile diets supplemented with phytase. Indonesian Fisheries Research Journal, 11, 73-80.

[6] Shapawi, R., Ng, W.K. and Mustafa, S. (2007) Replacement of fish meal with poultry by-product meal in diets formulated for the humpback grouper, Cromileptes altivelis. Aquaculture, 237, 118-126. doi:10.1016/j.aquaculture.2007.09.014

[7] Lin, H., Liu, Y., Tian, L., Wang, J., Zheng, W., Huang, J. and Chen, P. (2004) Apparent digestibility coefficients of arious feed ingredients for grouper Epinephelus coioides. Journal of World Aquaculture Society, 35, 134-142. doi:10.1111/j.1749-7345.2004.tb01069.x

[8] Association of Official Analytical Chemists International (AOAC International) (1990) Official Methods of Analysis of AOAC International. 16th Edition, AOAC International, Arlington.

[9] Furukawa, A. and Tsukahara, H. (1966) On the acid digestion method for the determination of chromic oxide as an index substance in the study of digestibility of fish diet. Bulletin of the Japanese Society of Scientific Fisheries, 32, 502-506. doi:10.2331/suisan.32.502

[10] Fowler, L.G. (1980) Substitution of soybean and cottonseed products for fishmeal in diets fed to Chinook and coho salmon. Progressive Fish Culturist, 42, 86-91. doi:10.1577/1548-8659(1980)42[87:SOSACP]2.0.CO;2

[11] Hajen, W.E., Higgs, D.A., Beames, R.M. and Dosanjh, B.S. (1993) Digestibility of various dietstuffs by post juvenile Chinook salmon (Oncorhynchus tshawytscha) in sea water: Measurement of digestibility. Aquaculture, 112, 333-348. doi:10.1016/0044-8486(93)90394-E

[12] Boonyaratpalin, M., Suraneiranat, P. and Tunpibal, T. (1998) Replacement of fish meal with various types of soybean products in diets for Asian seabass, Lates calcarifer. Aquaculture, 161, 67-78. doi:10.1016/S0044-8486(97)00257-3

[13] Tomás, A., De La Gándara, F., Garcia-Gomez, A., Pérez, L. and Jover, M. (2005) Utilization of soybean meal as an alternative protein source in the Mediterranean yellowtail, Seriola dumerili. Aquaculture Nutrition, 11, 333-340. doi:10.1111/j.1365-2095.2005.00365.x

[14] Ogunkoya, A.E. Page, G.I., Adewolu, M.A. and Bureau, D.P. (2006) Dietary incorporation of soybean meal and exogeneous enzyme cocktail can affect physical characteristics of faecal material egested by rainbow trout $(\mathrm{On}$ corhynchus mykiss). Aquaculture, 254, 166-175. doi:10.1016/j.aquaculture.2005.10.032

[15] NRC (National Research Council) (1993) Nutrition requirements of fish. National Academic Press, Washington DC.

[16] Cain K.D. and Garling D.L. (1995) Pretreatment of soybean meal with phytase for salmonid diets to reduce phosphorus concentrations in hatchery effluents. Progressive of Fish Culturist, 57, 114-119. doi:10.1577/1548-8640(1995)057<0114:POSMWP $>2.3$. $\underline{\mathrm{CO} ; 2}$
[17] Riche, M. and Brown P.B. (1996) Availability of phosphorus from feedstuffs fed to rainbow trout, Oncorhynchus mykiss. Aquaculture, 142, 269-282. doi:10.1016/0044-8486(95)01218-4

[18] Francis, G., Makkar, H.P.S. and Becker, K. (2001) Antinutritional factors present in plant derived alternate fish diet ingredients and their effects in fish. Aquaculture, 199, 197-227. doi:10.1016/S0044-8486(01)00526-9

[19] Portz, L. and Liebert, F. (2004) Growth, nutrient utilization and parameters of mineral metabolism in Nile tilapia Oreochromis niloticus (Linnaeus, 1758) fed plant-based diets with graded levels of microbial phytase. Journal of Animal Physiology Animal Nutrition, 88, 311-320. doi:10.1111/j.1439-0396.2004.00486.x

[20] Lim, S.J. and Lee, K.-J. (2009) Partial replacement of fishmeal by cottonseed meal and soybean meal with iron and phytase supplementation for parrot fish Oplegnathus fasciatus. Aquaculture, 290, 283-289. doi:10.1016/j.aquaculture.2009.02.018

[21] Dias, J., Yúfera, M., Valente, L.M.P. and Rema, P. (2010) Diet transit and apparent protein, phosphorus and energy digestibility of practical diet ingredients by Senegalese sole (Solea senegalensis). Aquaculture, 302, 94-99. doi:10.1016/j.aquaculture.2010.02.013

[22] Williams, I., Williams, K.C., Smith, D.M. and Jones, M. (2006) Polka-dot grouper, Cromileptes altivelis, can utilize dietary fat efficiently. Aquaculture Nutrition, 12, 379. 387. doi:10.1111/j.1365-2095.2006.00437.x

[23] Usman, Rachmansyah, Palingi, N.N. and Ahmad, T. (2007) Utilization of local feed ingredients in tiger grouper grow out moist diets. Aquaculture Asia Magazine, 33-36.

[24] Chen, W., Ai, Q., Mai, K., Xu, W., Liufu, Z., Zhang, W. and Cai, Y. (2011) Effects of dietary soybean saponins on diet intake, growth performance, digestibility and intestinal structure in juvenile Japanese flounder (Paralichthys olivaceus). Aquaculture, 318, 95-100. doi:10.1016/j.aquaculture.2011.04.050

[25] Storebakken, T., Kvien, I.S., Shearer, K.D., GrisdaleHelland, B., Helland, S.J. and Berge, G.M. (1998) The apparent digestibility of diets containing fishmeal, soybean meal or bacterial meal fed to Atlantic salmon (Salmo salar L). Comparative Biochemistry and Physiology Part A: Molecular and Integratyive Physiology, 147, 25-36.

[26] Tibaldi, E., Hakim, Y., Uni, Z., Tulli, F., Francesco, M., Luzzana, U. and Harpaz, S. (2006) Effects of the partial substitution of dietary fish meal by differently processed soybean meals on growth performance, nutrient digestibility and activity of intestinal brush border enzymes in European seabass (Dicentrartchus labrax). Aquaculture, 261, 182-193. doi:10.1016/j.aquaculture.2006.06.026

[27] Venou, B., Alexis, M.N., Fountoulaki, E. and Haralabous, J. (2006) Effects of extrusion and inclusion level of soybean meal on diet digestibility, performance and nutrient utilization of gilthead sea bream (Sparus aurata). Aquaculture, 261, 343-356.

doi:10.1016/j.aquaculture.2006.07.030 